Published July 2018

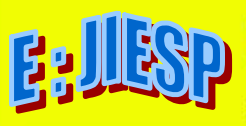

EKONOMIKAWAN : Jurnal Ilmu Ekonomi dan Studi Pembangunan

ISSN : 1693-7600 (Print), ISSN : 2598-0157 (Online), http://jurnal.umsu.ac.ld/index.php/ekawan

\title{
Pengaruh Penerimaan Pajak Hotel dan Pajak Restoran Terhadap \\ Pendapatan Asli Daerah (PAD) pada Badan Pengelolaan Pajak dan Retribusi Daerah Kota Medan
}

\author{
Arnida Wahyuni ${ }^{1}$ \\ Rinie Utara ${ }^{2}$ \\ Universitas Islam Negeri Sumatera Utara, Jalan Williem Iskandar Pasar V, Kenangan \\ Baru, Medan Estate, Percut Sei Tuan, Sumatera Utara, 20371 \\ e-mail:arnidawahyuni@yahoo.com
}

\begin{abstract}
ABSTRAK
Untuk melaksanakan dan menyelenggarakan otonomi daerah secara luas dan bertanggung jawab, diperlukan kewenangan dan kemampuan daerah untuk menggali sumber-sumber keuangan sendiri agar dapat melaksanakan fungsinya secara efektif dan efisien dalam bidang pemerintahan dan pelayanan umum kepada masyarakat. Dengan ditetapkannya Tarif Pajak Hotel dan Pajak Retoran sesuai dengan Undang-Undang Nomor 28 Tahun 2009 Pasal 35 dan Pasal 40 sebesar $10 \%$, maka setiap hotel dan restoran akan memberikan $10 \%$ dari pendapatan atas jasa hotel dan pelayanan restoran kepada para konsumen yang menikmatinya. Pajak Hotel dan Pajak Restoran merupakan bagian dari sumber - sumber PAD yang sangat potensial di kota Medan dan memberikan kontribusi yang cukup besar bila dilihat dari komponen pajak daerah, karena kota Medan merupakan pintu gerbang dalam menerima arus kunjungan wisatawan lokal dan wisatawan asing untuk berkunjung ke daerah tujuan wisata Sumatera Utara. Fenomena yang terjadi hanya pada tingkat penerimaan Pajak Hotel tahun 2014 dan Pajak Restoran tahun 2015 yang telah mencapai target yang direncanakan. Dimana penerimaan Pajak Hotel pada tahun 2014 sebesar Rp. 81.642.581.350,74 sudah melebihi target sebesar Rp. 81.500.000.000 atau mencapai $100,17 \%$ dan penerimaan Pajak Restoran pada tahun 2015 sebesar Rp. 124.409.617.130,10 sudah melebihi target sebesar Rp. 123.215.837.083 atau mencapai 100,97\%. Akibat dari fenomena yang terjadi menandakan bahwa sumber- sumber Pendapatan Asli Daerah (PAD) seperti Pajak Hotel dan Pajak Restoran terus mengalami penurunan pada tahun-tahun sebelumnya yang mengakibatkan penerimaan Pendapatan Asli Daerah (PAD) pada tahun 2011 sampai dengan 2015 selalu tidak mencapai target yang telah ditetapkan.
\end{abstract}

Kata kunci : Pajak Hotel, Pajak Restoran, Pendapatan Asli Daerah 
Published July 2018

EKONOMIKAWAN : Jurnal Ilmu Ekonomi dan Studi Pembangunan

ISSN : 1693-7600 (Print), ISSN : 2598-0157 (Online), http://jurnal.umsu.ac.Id/index.php/ekawan

\title{
Effect of Hotel Tax Revenues and Restaurant Taxes on Regional Original Income (PAD) on the Tax Management Agency and Medan City Regional Retribution
}

\begin{abstract}
To carry out and carry out regional autonomy broadly and responsibly, regional authority and capability is needed to explore its own financial resources in order to carry out their functions effectively and efficiently in the field of government and public services to the community.

With the stipulation of Hotel Tax and Retirement Tax Rates in accordance with Law Number 28 of 2009 Article 35 and Article 40 of $10 \%$, then every hotel and restaurant will provide $10 \%$ of the income for hotel services and restaurant services to consumers who enjoy it. Hotel Taxes and Restaurant Taxes are part of the potential PAD sources in the city of Medan and provide a substantial contribution when viewed from the local tax component, because Medan City is the gateway to receiving the flow of local tourists and foreign tourists visiting the area North Sumatra tourist destination.The phenomenon th at occurred only at the level of 2014 Hotel Tax receipts and 2015 Restaurant Taxes which had reached the planned target. Where Hotel Tax receipts in 2014 amounted to Rp. 81,642,581,350.74 has exceeded the target of Rp. 81,500,000,000 or reach 100.17\% and Restaurant Tax receipts in 2015 amounted to $R p .124,409,617,130.10$ has exceeded the target of $R p .123,215,837,083$ or reach $100.97 \%$. The effect of the phenomenon indicates that the sources of Regional Original Income (PAD) such as Hotel Taxes and Restaurant Taxes continue to decline in previous years which resulted in the receipt of Regional Original Income (PAD) in 2011 to 2015 which did not always reach the target has been established.
\end{abstract}

Keywords: Hotel Tax, Restaurant Tax, Local Revenue 
Published July 2018

Fing

EKONOMIKAWAN : Jurnal Ilmu Ekonomi dan Studi Pembangunan

ISSN : 1693-7600 (Print), ISSN : 2598-0157 (Online), http://jurnal.umsu.ac.ld/index.php/ekawan

\section{PENDAHULUAN}

Negara Republik Indonesia sebagai negara Kesatuan yang menganut asas desentralisasi (semua urusan, tugas dan wewenang pelaksanaan pemerintahan diserahkan sepenuhnya kepada daerah) dalam penyelenggaraan pemerintahan, memberikan kesempatan dan keleluasaan kepada daerah untuk menyelenggarakan kebijakan otonomi daerah. Kebijakan tersebut yang mulai diberlakukan pada tanggal 1 Januari 2001. Tujuan otonomi daerah adalah untuk lebih meningkatkan pelayanan kepada masyarakat, pengembangan demokrasi, keadilan, pemerataan, dan pemeliharaan hubungan yang serasi antara pusat dan daerah serta antar - daerah.

Dengan berlakunya Undang-Undang Nomor 09 Tahun 2015 tentang Pemerintahan Daerah sebagaimana telah diubah beberapa kali terakhir dengan sebelumnya tentang Perubahan Kedua atas Undang-Undang Nomor 23 Tahun 2014 tentang Pemerintahan Daerah dan Undang-Undang Nomor 33 Tahun 2004 tentang Perimbangan Keuangan antara Pemerintah Pusat dan Pemerintahan Daerah, penyelenggaraan pemerintahan daerah dilakukan dengan memberikan kewenangan yang seluas-luasnya, disertai dengan pemberian hak dan kewajiban menyelenggarakan otonomi daerah dalam kesatuan sistem penyelenggaraan pemerintahan negara. Pajak daerah dan retribusi daerah merupakan bagian dari sumber pendapatan daerah yang penting guna membiayai pelaksanaan pemerintahan daerah.

Menurut Undang-Undang Nomor 28 Tahun 2009 Pasal 1, Pajak Hotel adalah pajak atas pelayanan yang disediakan oleh hotel. Sedangkan, yang dimaksud dengan hotel adalah fasilitas penyedia jasa penginapan/peristirahatan termasuk jasa terkait lainnya dengan dipungut bayaran, yang mencakup juga motel, losmen, gubuk pariwisata, wisma pariwisata, pesanggrahan, rumah penginapan dan sejenisnya, serta rumah kos dengan jumlah kamar lebih dari 10 (sepuluh). Dan Pajak Restoran adalah pajak atas pelayanan yang disediakan oleh restoran dan yang dimaksud dengan restoran adalah fasilitas penyedia makanan dan/atau minuman dengan dipungut bayaran, yang mencakup juga rumah makan, kafetaria, kantin, warung, bar, dan sejenisnya termasuk jasa boga/katering.

Dengan ditetapkannya Tarif Pajak Hotel dan Pajak Retoran sesuai dengan UndangUndang Nomor 28 Tahun 2009 Pasal 35 dan Pasal 40 sebesar 10\%, maka setiap hotel dan restoran akan memberikan $10 \%$ dari pendapatan atas jasa hotel dan pelayanan restoran kepada para konsumen yang menikmatinya. Pajak Hotel dan Pajak Restoran merupakan bagian dari sumber - sumber PAD yang sangat potensial di Kota Medan dan memberikan kontribusi yang cukup besar bila dilihat dari komponen pajak daerah, karena Kota Medan merupakan pintu gerbang dalam menerima arus kunjungan wisatawan lokal dan wisatawan asing untuk berkunjung ke daerah tujuan wisata Sumatera Utara.

Fenomena yang terjadi hanya pada tingkat penerimaan Pajak Hotel tahun 2014 dan Pajak Restoran tahun 2015 yang telah mencapai target yang direncanakan. Dimana penerimaan Pajak Hotel pada tahun 2014 sebesar Rp. 81.642.581.350,74 sudah melebihi target sebesar Rp. 81.500.000.000 atau mencapai 100,17\% dan penerimaan Pajak Restoran pada tahun 2015 sebesar Rp. 124.409.617.130,10 sudah melebihi target sebesar Rp. 123.215.837.083 atau mencapai 100,97\%. 
Published July 2018

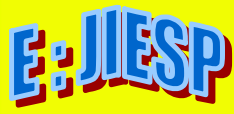

EKONOMIKAWAN : Jurnal Ilmu Ekonomi dan Studi Pembangunan

ISSN : 1693-7600 (Print), ISSN : 2598-0157 (Online), http://jurnal.umsu.ac.Id/index.php/ekawan

Akibat dari fenomena yang terjadi menandakan bahwa sumber-sumber Pendapatan Asli Daerah (PAD) seperti Pajak Hotel dan Pajak Restoran terus mengalami penurunan pada tahun-tahun sebelumnya yang mengakibatkan penerimaan Pendapatan Asli Daerah (PAD) pada tahun 2011 sampai dengan 2015 selalu tidak mencapai target yang telah ditetapkan.

\section{METODE}

Penelitian ini merupakan jenis penelitian kuantitatif, yaitu data penelitian berupa angka-angka dan analisis menggunakan statistik. Penulis mengadakan penelitian pada Badan Pengelolaan Pajak dan Retribusi Daerah Kota Medan di Jalan Jenderal Abdul Haris Nasution, No. 10, Pangkalan Masyhur, Medan Johor, Kota Medan, Sumatera Utara 20143, Indonesia. Waktu yang dibutuhkan penulis untuk menyelesaikan penelitian ini kurang lebih dari bulan Mei 2017 sampai dengan Juni 2017.

\section{HASIL PENELITIAN DAN PEMBAHASAN}

\section{Tabel 1}

Target dan Realisasi Pendapatan Asli Daerah Kota Medan

Tahun 2011 - 2015

\begin{tabular}{|c|c|c|c|}
\hline Tahun & Uraian & Target & Realisasi \\
\hline \multirow{5}{*}{2011} & Pendapatan Pajak Daerah & $585,029,048,289.00$ & $609,379,336,501.11$ \\
\hline & Hasil Retribusi Daerah & $376,939,628,894.00$ & $236,694,879,407.88$ \\
\hline & $\begin{array}{l}\text { Hasil Pengelolaan Kekayaan } \\
\text { Daerah yang Dipisahkan }\end{array}$ & $11,691,162,561.00$ & $11,727,355,511.57$ \\
\hline & $\begin{array}{l}\text { Lain - lain Pendapatan Asli } \\
\text { Daerah yang Sah }\end{array}$ & $136,809,754,019.00$ & $137,271,000,720.78$ \\
\hline & Pendapatan Asli Daerah & 1,110,469,593,763.00 & 995,072,572,141.34 \\
\hline \multirow{3}{*}{2012} & Pendapatan Pajak Daerah & $1,087,999,279,770.00$ & $892,674,245,233.74$ \\
\hline & Hasil Retribusi Daerah & $291,291,500,000.00$ & $127,839,652,517.53$ \\
\hline & Uraian & Target & Realisasi \\
\hline \multirow{3}{*}{2012} & $\begin{array}{l}\text { Hasil Pengelolaan Kekayaan } \\
\text { Daerah yang Dipisahkan }\end{array}$ & $18,491,162,561.00$ & $9,780,305,586.00$ \\
\hline & $\begin{array}{l}\text { Lain - lain Pendapatan Asli } \\
\text { Daerah yang Sah }\end{array}$ & $196,672,893,585.45$ & $117,607,258,270.11$ \\
\hline & Pendapatan Asli Daerah & $\mathbf{1 , 5 9 4 , 4 5 4 , 8 3 5 , 9 1 6 . 4 5}$ & $1,147,901,461,607.38$ \\
\hline \multirow{5}{*}{2013} & Pendapatan Pajak Daerah & $1,189,999,279,770.00$ & $881,346,719,012.01$ \\
\hline & Hasil Retribusi Daerah & $204,871,885,000.00$ & $188,459,795,126.50$ \\
\hline & $\begin{array}{l}\text { Hasil Pengelolaan Kekayaan } \\
\text { Daerah yang Dipisahkan }\end{array}$ & $8,957,540,954.00$ & $9,503,605,764.00$ \\
\hline & $\begin{array}{l}\text { Lain - lain Pendapatan Asli } \\
\text { Daerah yang Sah }\end{array}$ & $174,419,114,000.32$ & $126,859,589,245.22$ \\
\hline & Pendapatan Asli Daerah & $\mathbf{1 , 5 7 8 , 2 4 7 , 8 1 9 , 7 2 4 . 3 2}$ & $1,206,169,709,147.73$ \\
\hline 2014 & Pendapatan Pajak Daerah & $1,167,399,279,770.00$ & $962,728,267,172.53$ \\
\hline
\end{tabular}




\begin{tabular}{|c|c|c|c|}
\hline & Hasil Retribusi Daerah & $273,992,900,000.00$ & $171,006,302,216.00$ \\
\hline & $\begin{array}{l}\text { Hasil Pengelolaan Kekayaan } \\
\text { Daerah yang Dipisahkan }\end{array}$ & $6,823,791,825.00$ & $5,705,018,825.00$ \\
\hline & $\begin{array}{l}\text { Lain - lain Pendapatan Asli } \\
\text { Daerah yang Sah }\end{array}$ & $229,900,651,530.00$ & $244,806,526,516.09$ \\
\hline & Pendapatan Asli Daerah & $1,678,116,623,125.00$ & $1,384,246,114,729.62$ \\
\hline \multirow{5}{*}{2015} & Pendapatan Pajak Daerah & $1,267,102,579,446.00$ & $1,000,207,760,291.45$ \\
\hline & Hasil Retribusi Daerah & $205,010,390,000.00$ & $199,062,856,835.00$ \\
\hline & $\begin{array}{l}\text { Hasil Pengelolaan Kekayaan } \\
\text { Daerah yang Dipisahkan }\end{array}$ & $10,312,868,999.00$ & $8,523,731,824.00$ \\
\hline & $\begin{array}{l}\text { Lain - lain Pendapatan Asli } \\
\text { Daerah yang Sah }\end{array}$ & $312,278,935,567.45$ & $205,647,704,296.91$ \\
\hline & Pendapatan Asli Daerah & $1,794,704,774,012.45$ & $1,413,442,053,247.36$ \\
\hline
\end{tabular}

Tabel 2

Target dan Realisasi Pajak Hotel Kota Medan Tahun 2011 - 2015

\begin{tabular}{|c|c|c|c|c|}
\hline Tahun & Target (Rupiah) & Realisasi (Rupiah) & $\begin{array}{c}\text { Efektifitas } \\
(\%)\end{array}$ & $\begin{array}{c}\text { Pertumbuhan } \\
(\%)\end{array}$ \\
\hline 2011 & $66,903,789,500.00$ & $54,668,966,646.09$ & 81.71 & - \\
\hline 2012 & $81,000,000,000.00$ & $64,574,093,185.86$ & 79.72 & 18.12 \\
\hline 2013 & $81,000,000,000.00$ & $76,053,892,503.05$ & 93.89 & 17.78 \\
\hline Tahun & Target & Realisasi & $\begin{array}{c}\text { Efektifitas } \\
(\%)\end{array}$ & $\begin{array}{c}\text { Pertumbuhan } \\
(\%)\end{array}$ \\
\hline 2014 & $81,500,000,000.00$ & $81,642,581,350.74$ & 100.17 & 7.35 \\
\hline 2015 & $87,980,801,593.00$ & $82,304,995,232.53$ & 93.55 & 0.81 \\
\hline \multicolumn{3}{|c|}{ Rata - rata } & 89.81 & 8.81 \\
\hline
\end{tabular}

Tabel 3

Target dan Realisasi Pajak Restoran Kota Medan Tahun 2011 - 2015

\begin{tabular}{|c|c|c|c|c|}
\hline Tahun & Target (Rupiah) & Realisasi (Rupiah) & $\begin{array}{c}\text { Efektifitas } \\
(\%)\end{array}$ & $\begin{array}{c}\text { Pertumbuhan } \\
(\%)\end{array}$ \\
\hline 2011 & $96,209,441,389.00$ & $70,485,458,321.76$ & 73.26 & - \\
\hline 2012 & $113,209,441,000.00$ & $83,182,567,950.56$ & 73.48 & 18.01 \\
\hline 2013 & $113,209,441,000.00$ & $91,590,223,058.75$ & 80.90 & 10.11 \\
\hline 2014 & $113,209,441,000.00$ & $106,429,552,172.14$ & 94.01 & 16.20 \\
\hline 2015 & $123,215,837,083.00$ & $124,409,617,130.10$ & 100.97 & 16.89 \\
\hline \multicolumn{3}{|c|}{ Rata - rata } & 84.52 & 15.30 \\
\hline
\end{tabular}


Published July 2018

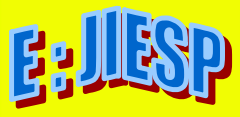

EKONOMIKAWAN : Jurnal Ilmu Ekonomi dan Studi Pembangunan

ISSN : 1693-7600 (Print), ISSN : 2598-0157 (Online), http://jurnal.umsu.ac.Id/index.php/ekawan

Berdasarkan penyajian data hasil penelitian, maka penulis akan membahas hasil penelitian sesuai dengan permasalahan yang diajukan.

1. Pengaruh penerimaan Pajak Hotel terhadap pendapatan Asli Daerah Kota Medan Tahun 2011 - 2015

Hasil pengujian dalam penelitian ini menunjukan bahwa Pajak hotel berpengaruh positif dan signifikan terhadap Pendapatan Asli Daerah. Hal tersebut didukung dengan nilai signifikan sebesar $\alpha=5 \%$ dengan $\mathrm{t}-$ hitung $>\mathrm{t}-$ tabel $(4.932611>2,101)$. Pengaruh positif ini menunjukkan bahwa apabila variabel pajak hotel mengalami kenaikan maka akan menyebabkan peningkatan pada variabel pendapatan asli daerah.

Hasil pengujian dalam penelitian ini menunjukkan bahwa kemampuan Badan Pengelolaan Pajak dan Retribusi daerah dalam merealisasikan Pajak Hotel yang direncanakan dibandingkan target yang ditetapkan berdasarkan potensi riil daerah adalah kurang baik. Hal tersebut didukung dengan tingkat rata-rata rasio efektifitas Pajak Hotel kota Medan yang kurang dari $100 \%$ atau rata-rata sebesar $89.81 \%$ setiap tahunnya. Hal ini menunjukan bahwa kinerja dalam penerimaan pajak hotel kota Medan kurang baik. Karena realisasi pajak hotel lebih kecil dari pada target yang di rencanakan atau yang ditetapkan. Kemampuan daerah dalam menjalankan tugas dikategorikan efektif apabila rasio yang dicapai minimal sebesar 1 (satu) atau 100 persen.

Hasil pengujian dalam penelitian ini menunjukkan bahwa kemampuan Badan Pengelolaan Pajak dan Retribusi daerah dalam mempertahankan dan meningkatkan keberhasilan yang telah dicapai dari periode ke periode berikutnya adalah kurang baik. Hal tersebut didukung dengan selama lima tahun terus terjadi penurunan di rasio pertumbuhan tapi jika di bandingkan dengan tahun pertama rasio pertumbuhan jauh lebih baik. Pada tahun 2011 - 2012 sebesar 18.12\%,ini merupakan persentase tertinggi dan pada tahun 2015 - 2014 sebesar $0.81 \%$, ini merupakan persentase terendah. Jadi bisa di katakan selama lima tahun ini terus terjadi penurunan di rasio pertumbuhan tapi jika di bandingkan dengan tahun pertama rasio pertumbuhan jauh lebih baik. Dengan mengetahui pertumbuhan Pajak Hotel, maka dapat dilakukan evaluasi terhadap potensipotensi daerah yang perlu mendapat perhatian.

\section{Pengaruh penerimaan Pajak Restoran terhadap pendapatan Asli Daerah Kota Medan Tahun 2011 - 2015}

Hasil pengujian dalam penelitian ini menunjukan bahwa Pajak Restoran berpengaruh positif dan signifikan terhadap Pendapatan Asli Daerah. Hal tersebut didukung dengan nilai signifikan sebesar $\alpha=5 \%$ dengan $\mathrm{t}-$ hitung $>\mathrm{t}-$ tabel $(4.071726$ $>2,101)$. Pengaruh positif ini menunjukkan bahwa apabila variabel pajak restoran mengalami kenaikan maka akan menyebabkan peningkatan pada variabel pendapatan asli daerah. 
Published July 2018

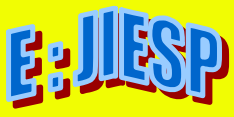

EKONOMIKAWAN : Jurnal Ilmu Ekonomi dan Studi Pembangunan

ISSN : 1693-7600 (Print), ISSN : 2598-0157 (Online), http://jurnal.umsu.ac.Id/index.php/ekawan

Hasil pengujian dalam penelitian ini menunjukkan bahwa kemampuan Badan Pengelolaan Pajak dan Retribusi daerah dalam merealisasikan Pajak Restoran yang direncanakan dibandingkan target yang ditetapkan berdasarkan potensi riil daerah adalah kurang baik. Hal tersebut didukung dengan tingkat rata-rata rasio efektifitas Pajak Hotel kota Medan yang kurang dari $100 \%$ atau rata-rata sebesar $84.52 \%$ setiap tahunnya. Hal ini menunjukan bahwa kinerja dalam penerimaan pajak restoran Kota Medan kurang baik. Karena realisasi pajak restoran lebih kecil dari pada target yang di rencanakan atau yang di tetapkan. Kemampuan daerah dalam menjalankan tugas dikategorikan efektif apabila rasio yang dicapai minimal sebesar 1 (satu) atau 100 persen.

Hasil pengujian dalam penelitian ini menunjukkan bahwa kemampuan Badan Pengelolaan Pajak dan Retribusi daerah dalam mempertahankan dan meningkatkan keberhasilan yang telah dicapai dari periode ke periode berikutnya adalah kurang baik. Hal tersebut didukung dengan selama lima tahun terus terjadi penurunan di rasio pertumbuhan tapi jika di bandingkan dengan tahun pertama rasio pertumbuhan jauh lebih baik. Pada tahun 2011-2012 sebesar 18.01\%, ini merupakan persentase tertinggi, pada tahun 2012-2013 sebesar $10.11 \%$, ini merupakan persentase terendah dan pada tahun 2015-2014 sebesar 16.89\%. Jadi bisa di katakan selama lima tahun ini terus terjadi penurunan di rasio pertumbuhan tapi jika di bandingkan dengan tahun pertama rasio pertumbuhan jauh lebih baik. Dengan mengetahui pertumbuhan Pajak Restoran, maka dapat dilakukan evaluasi terhadap potensi-potensi daerah yang perlu mendapat perhatian.

\section{Pengaruh Penerimaan Pajak Hotel dan Pajak Restoran terhadap peningkatan pendapatan Asli Daerah Kota Medan Tahun 2011 - 2015}

Hasil pengujian dalam penelitian ini menunjukan bahwa Pajak Hotel, Pajak restoran berpengaruh positif dan signifikansi terhadap Pendapatan Asli Daerah. Hal tersebut didukung dengan nilai signifikan sebesar $\alpha=5 \%$ dengan $\mathrm{F}-$ hitung $>$ dari $\mathrm{F}-$ tabel (205.8267 > 3.55). Pengaruh positif ini menunjukkan bahwa apabila variabel pajak hotel dan pajak restoran mengalami kenaikan maka akan menyebabkan peningkatan pada variabel pendapatan asli daerah.

Hal tersebut didukung dengan tingkat rata-rata rasio efektifitas Pajak Hotel kota Medan yang kurang dari $100 \%$ atau rata-rata sebesar $79.85 \%$ setiap tahunnya. Hal ini menunjukan bahwa kinerja dalam penerimaan pajak restoran kota Medan kurang baik. Karena realisasi pajak restoran lebih kecil dari pada target yang di rencanakan atau yang di tetapkan. Kemampuan daerah dalam menjalankan tugas dikategorikan efektif apabila rasio yang dicapai minimal sebesar 1 (satu) atau 100 persen. .

Hasil pengujian dalam penelitian ini menunjukkan bahwa kemampuan Badan Pengelolaan Pajak dan Retribusi daerah dalam mempertahankan dan meningkatkan keberhasilan yang telah dicapai dari periode ke periode berikutnya adalah kurang baik. Hal tersebut didukung dengan selama lima tahun terus terjadi penurunan di rasio pertumbuhan tapi jika di bandingkan dengan tahun pertama rasio pertumbuhan jauh lebih baik. Pada 2011 - 2012 sebesar 15.36\%, ini merupakan persentase tertinggi dan pada tahun 2014 - 2015 sebesar $2.11 \%$, ini merupakan persentase terendah. 
Published July 2018

E⿹丁口

EKONOMIKAWAN : Jurnal Ilmu Ekonomi dan Studi Pembangunan

ISSN : 1693-7600 (Print), ISSN : 2598-0157 (Online), http://jurnal.umsu.ac.ld/index.php/ekawan

Jadi bisa di katakan selama lima tahun ini terus terjadi penurunan di rasio pertumbuhan tapi jika di bandingkan dengan tahun pertama rasio pertumbuhan jauh lebih baik. Dengan mengetahui pertumbuhan Pajak Restoran, maka dapat dilakukan evaluasi terhadap potensi - potensi daerah yang perlu mendapat perhatian.

\section{SIMPULAN}

1. Berdasarkan hasil penelitian yang dilakukan pada Badan Pengelolaan Pajak dan Retribusi Daerah Kota Medan, dapat disimpulkan bahwa Kemampuan daerah dalam meningkatkan dan mempertahankan tingkat penerimaan pajak hotel dan pajak restoran dari tahun ke tahun berikutnya adalah kurang baik. Hal tersebut dapat dilihat dari tingkat pertumbuhan yang semakin rendah dari tahun ke tahun berikutnya. Begitu juga dengan Efektifitas penerimaan pajak hotel dan pajak restoran terhadap pendapatan asli daerah adalah kurang baik. Hal tersebut dapat dilihat dari:

2. Realisasi pajak hotel pada tahun 2011 sebesar Rp. 54.668.966.646,09 tidak mencapai target pajak hotel sebesar Rp. 66.903.789.500. Pada tahun 2012 realisasi pajak hotel sebesar Rp. 64.574.093.185,86 tidak mencapai target pajak hotel sebesar Rp. 81.000.000.000. Pada Tahun 2013 realisasi pajak hotel sebesar Rp. 76.053.892.503,05 tidak mencapai target pajak hotel sebesar Rp. 81.000.000.000 dan pada tahun 2015 realisasi pajak hotel sebesar Rp. 82.304.995.232,53 tidak mencapai target pajak hotel sebesar Rp. 87.980.801.593. Hanya pada tahun 2014 realisasi pajak hotel sebesar Rp. 81.642.581.350,74 berhasil melebihi target yang telah ditetapkan sebesar Rp. 81.500 .000 .000 .

3. Realisasi pajak restoran pada tahun 2011 sebesar Rp. 70.485.458.321,76 tidak mencapai target pajak restoran sebesar Rp. 96.209.441.389. Pada tahun 2012 realisasi pajak restoran sebesar Rp. 83.182.567.950,56 tidak mencapai target pajak restoran sebesar Rp. 113.209.441.000. Pada Tahun 2013 realisasi pajak restoran sebesar Rp. 91.590.223.058,75 tidak mencapai target pajak restoran sebesar Rp. 113.209.441.000 dan pada tahun 2014 realisasi pajak restoran sebesar Rp. 106.429.552.172,14 tidak mencapai target pajak restoran sebesar Rp. 113.209.441.000. Hanya pada tahun 2015 realisasi pajak restoran sebesar Rp. 124.409.617.130,10 berhasil melebihi target yang telah ditetapkan sebesar Rp. 123.215.837.083.

4. Realisasi pendapatan asli daerah pada tahun 2011 sebesar Rp 995.072.572.141,34 tidak mencapai target pendapatan asli daerah sebesar Rp 1.110.469.593.763. Pada tahun 2012 realisasi pendapatan asli daerah sebesar $\mathrm{Rp}$ 1.147.901.461.607,38 tidak mencapai target pendapatan asli daerah sebesar Rp 1.594.454.835.916,45. Pada Tahun 2013 realisasi pendapatan asli daerah sebesar Rp 1.206.169.709.147,73 tidak mencapai target pendapatan asli daerah sebesar Rp 1.578.247.819.724,32. Pada tahun 2014 realisasi pendapatan asli daerah sebesar Rp 1.384.246.114.729,62 tidak mencapai target pendapatan asli daerah sebesar Rp 1.678.116.623.125 dan Pada tahun 2015 realisasi pendapatan asli daerah sebesar $\mathrm{Rp}$ 1.413.442.053.247,36 tidak mencapai target pendapatan asli daerah sebesar Rp 1.794.704.774.012,45. 
Published July 2018

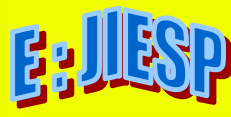

EKONOMIKAWAN : Jurnal Ilmu Ekonomi dan Studi Pembangunan

ISSN : 1693-7600 (Print), ISSN : 2598-0157 (Online), http://jurnal.umsu.ac.Id/index.php/ekawan

5. Variabel Pajak Hotel (PH) berpengaruh positif terhadap PAD Kota Medan, hal ini ditunjukkan oleh koefisien PH sebesar 0.390944. Artinya setiap kenaikan Pajak Hotel sebesar 1 milyar, maka akan mengakibatkan naiknya PAD Kota Medan sebesar 0.390944 milyar rupiah selama kurun waktu 2011-2015. Dan variabel Pajak Restoran (PR) berpengaruh positif terhadap PAD Kota Medan, hal ini ditunjukkan oleh koefisien PR sebesar 0.350588. Artinya setiap kenaikan Pajak Restoran sebesar 1 milyar, maka akan mengakibatkan meningkatkan PAD Kota Medan sebesar 0.350588 milyar rupiah selama kurun waktu 2011-2015.

6. Berdasarkan hasil pengujian didapat nilai Uji $\mathrm{F}$ - Statistik, diketahui bahwa $\mathrm{F}$ - hitung lebih besar dari F - tabel (205.8267 > 3.55). Dengan demikian, secara bersama - sama variabel pajak hotel dan pajak restoran berpengaruh terhadap jumlah Pendapatan Asli Daerah Kota Medan. Pajak hotel berpengaruh positif dan signifikan terhadap pendapatan asli daerah kota Medan periode 2011 - 2015, hal ini dapat diliat pada uji $\mathrm{t}-$ statistik $(\alpha=5 \%$ dengan $\mathrm{t}-$ hitung $>\mathrm{t}-$ tabel $(4.932611>2,101))$. Pajak restoran berpengaruh positif dan signifikan terhadap pendapatan asli daerah kota Medan periode $2011-2015$, hal ini dapat diliat pada uji $\mathrm{t}-$ statistik $(\alpha=5 \%$ dengan $\mathrm{t}-$ hitung $>\mathrm{t}-$ tabel $(4.071726>2,101))$. Korelasi pajak hotel dan pajak restoran dengan nilai determinasi (R2) sebesar 0.966834 yang berarti bahwa korelasi atau hubungan antara Pendapatan Asli Daerah dengan Pajak Hotel dan Pajak Restoran adalah erat dan positif. Hasil dari penerimaan pajak hotel dan pajak restoran terhadap pendapatan asli daerah selama 5 tahun adalah sebesar $96.68 \%$ yang artinya pajak hotel dan pajak restoran berpengaruh terhadap PAD, sedangkan sisanya sebesar $3.32 \%$ dipengaruhi oleh faktor lain

\section{DAFTAR PUSTAKA}

Alisman, 2015. Analisis Faktor-Faktor Yang Memengaruhi Penerimaan Pajak Hotel Di Kabupaten Aceh Barat. dalam Jurnal Ekonomi Dan Kebijakan Publik, Volume 2 Nomor 1.

Departemen Agama RI. 2011. Al - Qur'an dan Terjemahan. CV Darus Sunnah: Jakarta.

Chandra, Ervina Yulia. 2015. Pengaruh Pemungutan Pajak Restoran, Pajak Hotel dan Pajak Hiburan dalam meningkatkan Pendapatan Asli Daerah pada Dinas Pendapatan Asli Daerah Kota Bekasi Periode 2004-2013. Skripsi, Universitas Darma Persada

Gusfahmi. 2011. Pajak menurut Syari'ah - Edisi Revisi. Jakarta: Rajawali Pers

Kurniawan, Albert. 2014. Metode Riset untuk Ekonomi \& Bisnis - Teori, Konsep \& Praktik Penelitian Bisnis. Bandung: Alfabeta

Maipita, Indara. 2010. Metode Penelitian Bisnis Untuk Akuntansi dan Managemen. Yogyakarta: Digibooks

Mardiasmo. 2013. Perpajakan Edisi Revisi. Yogyakarta: Andi

Mardiasmo. 2016. Perpajakan Edisi Terbaru. Yogyakarta: Andi

Mustika, Winda Ayu. 2014. Kontribusi Pajak Daerah Dan Retribusi Terhadap Pendapatan Asli Daerah Di Pemerintah Kota Surabaya. Dalam Jurnal Ilmu \& Riset Akuntansi, Vol. 3 No. 6 
Published July 2018

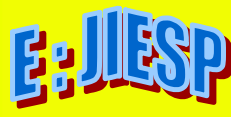

EKONOMIKAWAN : Jurnal Ilmu Ekonomi dan Studi Pembangunan

ISSN : 1693-7600 (Print), ISSN : 2598-0157 (Online), http://jurnal.umsu.ac.ld/index.php/ekawan

Nordiawan, Deddi, dkk., 2007, Akuntansi Pemerintahan, Penerbit Salemba Empat: Jakarta

Penyusun, Tim. 2011. Modul EViews 6, Unit Pengembangan Fakultas Ekonomika Universitas Diponegoro

Republik Indonesia, 2011, Peraturan Daerah Kota Medan Nomor 4 Tahun 2011 tentang Pajak Hotel. Diakses pada tanggal 12 Juli 2017.

Republik Indonesia, 2011, Peraturan Daerah Kota Medan Nomor 5 Tahun 2011 tentang Pajak Restoran. Diakses pada tanggal 12 Juli 2017.

Republik Indonesia, 2016, Peraturan Pemerintah Republik Indonesia Nomor 55 Tahun 2016 Tentang Ketentuan Umum dan Tata Cara Pemungutan Pajak Daerah. Diakses pada tanggal 12 Juli 2017.

Republik Indonesia, 2010, Peraturan Pemerintah Republik Indonesia Nomor 71 Tahun 2010 tentang Standar Akuntansi Pemerintahan. Diakses pada tanggal 12 Juli 2017.

Republik Indonesia, 2015, Undang - Undang Nomor 9 Tahun 2015 tentang Perubahan Kedua Atas Undang - Undang Nomor 23 Tahun 2014 tentang Pemerintahan Daerah. Diakses pada tanggal 12 Juli 2017.

Republik Indonesia, 2009, Undang - Undang Nomor 28 Tahun 2009 tentang Pajak Daerah dan Retribusi Daerah. Diakses pada tanggal 12 Juli 2017.

Republik Indonesia, 2004, Undang - Undang Nomor 33 Tahun 2004 tentang Perimbangan Keuangan antara Pemerintah Pusat dan Pemerintahan Daerah. Diakses pada tanggal 12 Juli 2017.

Ruswandi, Rina Rahmawati. 2009. Analisis Pengaruh Pajak Daerah Terhadap Pendapatan Asli Daerah (PAD) di Kabupaten Sumedang. Skripsi: IPB, 2009

Sarwono, Jonathan, 2016, Prosedur - prosedur Analisis Populer Aplikasi Riset dan Tesis dengan Eviews, Yogyakarta: Gava Media

Siahaan, Marihot Pahala. 2010. Hukum Pajak Materia: Objek, Subjek, Dasar Pengenaan Pajak, Tarif Pajak, dan Cara Perhitungan Pajak. Yogyakarta: Graha Ilmu

Siahaan, Marihot P. 2013. Pajak Daerah dan Retribusi Daerah. Jakarta: PT RajaGrafindo Persada

Sitompul, Mhd. Syahman, dkk., 2015, Akuntansi Masjid, Cetakan Pertama, Medan: Febi UIN - SU Press

Suprianto, Edy. 2011. Perpajakan di Indonesia. Yogyakarta: Graha Ilmu

Syafitri, Dhyni Inka, 2016, “Analisis Pertumbuhan dan Kontribusi Pajak Daerah, Retribusi Daerah, dan Lain-Lain PAD yang Sah terhadap Pendapatan Asli Daerah", dalam Jurnal Akuntansi Fakultas Ekonomi dan Bisnis Universitas Muhammadiyah Surakarta.

Yani, Ahmad. 2008. Hubungan Keuangan antara Pemerintah Pusat dan Daerah di Indonesia. Jakarta: PT RajaGrafindo Persada

Agus Sukoco dan Santirianingrum Soebandhi, Modul 8 Analisa Trend dan Forecasting, http://suci-rahma.mhs.narotama.ac.id/files/2013/06/Modul-8-Analisa-Trend-danforecasting.pdf, Diakses pada tanggal 09 Agustus 2017 pukul 12.11 WIB

Agus Sukoco dan Santirianingrum Soebandhi, Modul 8 Analisa Trend dan Forecasting, http://suci-rahma.mhs.narotama.ac.id/files/2013/06/Modul-8-Analisa-Trend-danforecasting.pdf, Diakses pada tanggal 09 Agustus 2017 pukul 12.11 WIB. 


\section{בג]|[SP EKONOMIKAWAN : Jurnal Ilmu Ekonomi dan Studi Pembangunan}

ISSN : 1693-7600 (Print), ISSN : 2598-0157 (Online), http://jurnal.umsu.ac.Id/index.php/ekawan

Dimaser, Indra, 2017, “Menghitung Laporan Realisasi anggaran Pemerintah Daerah",http://dimaseraketikajarikumenari.blogspot.co.id/2013/10/menghitung-

laporan-realisasi-anggaran.html, Diunduh pada tanggal 29 Juli 2017 pukul 22.00 WIB.

Gusfahmi, 2017,"Pajak Haramkah?, http://www.pajak.go.id/content/article/pajakharamkah". Diakses pada tanggal 26 April 2017 pukul 19.00 WIB.

Riadi, Muchlisin, 2017. "Pendapatan Asli Daerah", http://www.kajianpustaka.com/2015/06/pendapatan-asli-daerah-pad.html, diunduh pada tanggal 26 Juli 2017 pukul 14.00 WIB. 